\title{
Analysis of the Surface Subsidence of Porong and Surrounding Area, East Java, Indonesia based on Interferometric Satellite Aperture Radar (InSAR) Data
}

\author{
Indra Arifianto ${ }^{1}$, Rahmat C. Wibowo ${ }^{2 *}$ \\ ${ }^{1}$ Department Geological Engineering, Universitas Gadjah Mada, Yogyakarta, Indonesia. \\ ${ }^{2}$ Department Geophysical Engineering, Universitas Lampung, Bandar Lampung, Indonesia.
}

* Corresponding author: rahmat.caturwibowo@eng.unila.ac.id

Tel.: +6281327507517

Received: Jun 17, 2016; Accepted: Sept 21, 2020.

DOI: $10.25299 /$ jgeet.2020.5.4.5149

\begin{abstract}
Since 2006, the mud volcano erupted in the Porong area due to wellbore failure triggered by an earthquake (2006) epicenter in the Jogjakarta area. The mud volcano buried several villages with mud and continued erupted until today. Based on the InSAR data, it can be seen that the subsidence is still happening near the dam area and another area that is not related to mud volcano eruption such as the production of two gas fields in the Porong area. Moreover, the Porong area is flat and low, less than 4 meters above sea level. The analysis shows that the subsidence rate in this area is up to $0.5 \mathrm{~m} / \mathrm{yr}$. If this subsidence is continuing, the city can be sinking and flooding during the rainy season. The prediction result from this method is about 10 years more and 36 years since in 2006 based on the mudflow rate method.
\end{abstract}

Keywords: surface subsidence, InSAR, Porong, East Java

\section{Introduction}

The study area is located in the working area of one of the oil companies in Indonesia, namely Lapindo Brantas Ltd. The Brantas Production Sharing Contract (PSC) has a concession area of approximately $7,250 \mathrm{~km}^{2}$, which consists of three oil and gas fields in this area: Wunut (WU), Carat (CA), and Tanggulangin (TA) (see Fig. 1). In May 2006, the company drilled an exploration well in this area (Banjar Panji-1 well) and targeted reservoir in Miocene Kujung Limestone (Sawolo et al., 2010). However, during the drilling, the well penetrated a thick formation of under compacted shale of Pliocene Upper Kalibeng Formation (from $900 \mathrm{~m}$ to $1,871 \mathrm{~m}$ ). This formation is characterized by a low-velocity interval (Figure 1). The borehole was cased down to 1,091 m (Pucangan Fm.). After the well had penetrated to a total depth of 2,834 m (Kujung Fm), this time without a protective casing and they stop the operation by putting a cement plug in the steel casing. Unfortunately, the Jogjakarta earthquake (2006) trigger and reactivated Watukosek fault that crosses the well location, which makes the mud is flowing from overpressure formation to surface through the existing fault, where the first eruption is about $200 \mathrm{~m}$ southwest of the Banjar Panji-1 well.

Since it started to erupt on the $29^{\text {th }}$ of May 2006, the remaining lifespan of the Lusi eruption is still questionable. However, it is in stable condition recently, and yet, no signs that the mudflow will stop to flow. Where initially, the mud eruption up to $180,000 \mathrm{~m}^{3} /$ day with the subsidence rate is up to $5 \mathrm{~cm} /$ day in the central vent (Abidin et al., 2008 and Istadi et al., 2009). The mud covers area about $7 \mathrm{~km}^{2}$, and the subsidence area may cover up to $100 \mathrm{~km}^{2}$ (Davies et al., 2011). In the mid of 2011, the mud is remaining to expulse with a discharge rate of 10,000 $\mathrm{m}^{3} /$ day, although it was decreased significantly from previous years when mud is flow at $100,000 \mathrm{~m}^{3} / \mathrm{day}$, it was expected that the mudflow would continue for next 25 to 30 years. This eruption has a devastating effect on the Porong District of Eastern Java; The flow of mud and ground surface deformation has caused significant physical, environmental, economic, and social damage to the local and regional communities. Although the clay is continuing erupting, the area is also growing as a satellite city of Surabaya and Sidoarjo since this area is a very strategic location for business and located in the main transportation route in the East Java area.

Since this area is experiencing deformation on the surface due to subsurface material eruption, we can use the Interferometric Sattelite Aperture Radar (InSAR) methodology to study the deformation rate through time in this area. By doing time series analysis, we also can predict when the mud volcano will stop to erupt since we know that the mud eruption decreased exponentially through time and very closely related to the subsidence rate as the side effect of the mud eruption. This result of this research will also be compared to an investigation of studying the probabilities calculation of the longevity mud eruption based on the geotechnical aspect by Davies et al. (2011).

\section{Geology}

The basement configuration has a NE-SW structural orientationand comprises a series of well-defined basement ridges withintervening grabens serving as depocenters, which contain Tertiary sediments. Clastic sediment deposition and carbonate buildup ofthe Ngimbang Formation took place during the Eocene and Early Oligocene. The Late Oligocene and Miocene sequence is separated from the underlying sequence by an unconformity that served asthe foundation of ENEWSW oriented carbonate trends. This platform development, which is known as the Kujung limestone,occurred in the late Oligocene while the Prupuh and Tuban reefaldevelopment took 
place in the Early to Middle Miocene. The latestand most pronounced period of compressional tectonism began inthe Late Miocene time and continued episodically into the Pleistocene. The resulting transpressional regime caused the left-lateralmovement that runs East-West which resulted in an East-Westorientation of the anticline structures (Istadi et al., 2009).

Subsequent Pliocene and Pleistocene sedimentation consistedof an Eastward-prograding mudstone dominated volcaniclastic wedge of Kalibeng and Pucangan Formation, with a thickness of $2400-3000 \mathrm{~m}$. The volcaniclastic materials are derived from theJava volcanic arc south of the Sidoarjo area. Themudstone of theKalibeng Formation is over-pressured in most parts of the basinwhere the rapid pressure transition occurs. The high sedimentationrate, rapid deposition and burial of thick shale in the depocenters that occurred during Pliocene and Pleistocene haveresulted inzones of under-compacted shales (Willumsen and Schiller, 1994;Schiller et al., 1994). This highly plastic zone is over-pressured dueto the presence of excessive trapped water and maturing organic-rich materials. The many mud volcanoes found in East and CentralJava correlate with this thick and rapidly deposited claybearingKalibeng Formation sediments.

The active tectonics coupled with over-pressured maturingorganic-rich sediments makes East Java an ideal setting for mudvolcanism. The existence of the NE-SW trending Watukosek faultsystem in the LUSI area provides the necessary conduit for mud,fluid and gases extruding from a deep horizon to flow up to thesurface to form the LUSI mud volcano (Istadi et al., 2009).

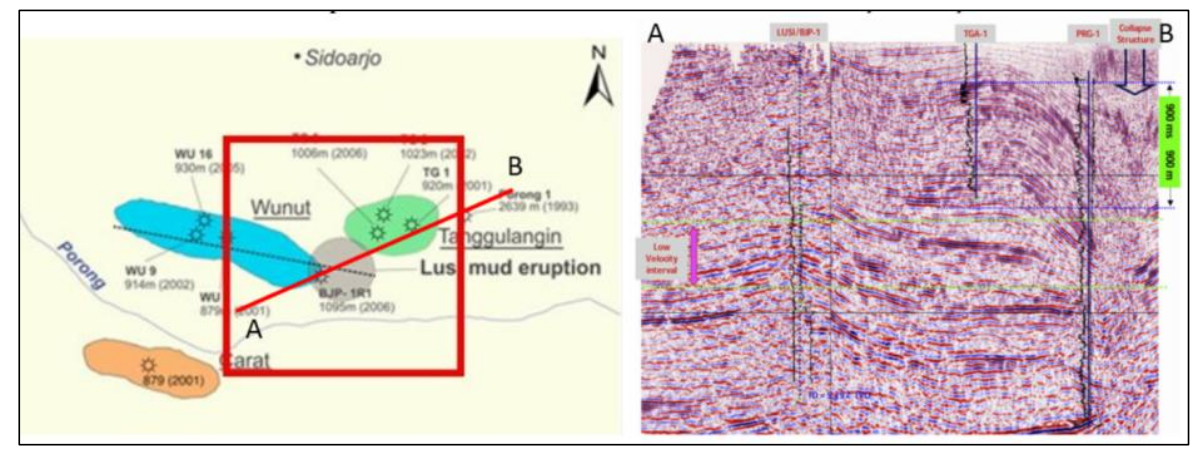

Fig.1. The study area is $10 \times 10 \mathrm{~km}$ located in the south of Sidoarjo city (left) and the NE-SW seismic line show subsurface formation and the mud volcano source (right) (Istadi et al., 2009)

\section{Methods}

\subsection{Data Source}

In this paper, we used 27 SAR images from ascending data, acquired by the Sentinel-1 satellite between January 2019 and April 2020. The spatial and temporal baseline ranged from 15 to $250 \mathrm{~m}$ and 12 days to 48 days, respectively.

Gamma software was applied to perform the interferometric process, and included the following steps: master image selection, topographicphase removal, and interferogram generation. In the study, we employed the SBAStechnology to acquire land subsidence information. The topographic phase was removed by using the $90 \mathrm{~m}$ resolution Shuttle Radar Topography Mission (SRTM) DEM data from the United States Geological Survey (USGS). The spatial adaptive filter and temporal filter were applied to separate the atmospheric phase, noise phase, and nonlinear deformation phase. Then, two-dimensional spatial high-pass filtering was used to remove the orbital linear ramp and other longwavelength noise from the differential interferograms. A total of 27 interferogram pairs were built with spatial and temporal baselines smaller than $250 \mathrm{~m}$ and 24 days, respectively (Fig. 2).

\subsection{SB Technique}

In SB methods (see, e.g. Berardino et al., 2002; Schmidt et al., 2003), a network of inter ferogram pairs is created with small temporal and geometrical baselines to limit decorrelation noise. Noise is further reduced by applying range and azimuth filters (Just et al., 1994) and spatial multi-looking. However, filtering reduces spatial resolution, which can fail to detect some stable isolated pixels. We use the full-resolution SB method of Hooper (2008), in which pixels are identified among the candidate pixels, based on phase analysis. For SB processing, we form interferograms with an estimated mean coherence above a threshold of 0.5 . We also add additional connections to ensure that there are no isolated clusters of images (see Fig.2), creating a total of 27 interferograms.

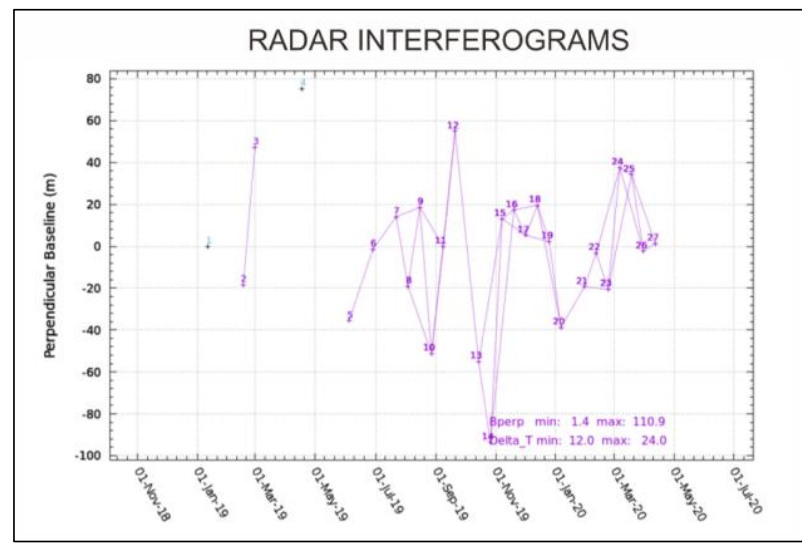

Fig.2. A network of interferogram pairs obtained from Sentinel-1 used in small baseline subset(SBAS) InSAR, circles represent images and lines represent the interferograms formed. InSAR Network Build set the spatial $250 \mathrm{~m}$ and temporal baselines 24 days

\section{Results and Discussion}

\subsection{Results}

The first image processing result is the interferogram SAR image. This image clearly shows the effect of surface condition on the coherence and decorrelation. From satellite image, city or village have good coherence in the InSAR phase image, while vegetation or plantation area show scattered temporal decorrelation. This scattered could happen due to the randomness of the phase by the signal reflection of the trees.

The interferometric SAR image generates the deformation phase, noise phase, and the atmospheric signal. Later on, this Atmospheric signal will be reduced and neglected for small scale area or deformation. Furthermore, some decorrelation and speckle noise can be removed by applying some filtering parameters. Since we have several temporal decorrelations in our area, we can use adaptive filtering to reduce the noise on 
our data without changing the pixel size. To do the adaptive filter is to adapt the local slope before averaging the value. In Gamma, the adaptive program filter is used for complex-valued images, such as interferograms. This operation helps to reduce decorrelation noise and improves the appearance of the InSAR phase and helps in the unwrapping phase.

For the incoherent area, we can apply masking in the software to remove lousy phase data. In this study area, bad coherence area exists inside the LUSI dam, where the study target area. Therefore, we don't use the masking image to analyze displacement near the vent of the mud volcano. Image result from the processing that we use for analysis is mainly an unwrapping image because we will investigate the displacement in a metric unit in LOS (line of sight) view. In this study, we use Geocode, LOS, filtered unwrapping image to do time series analysis.

First of all, we need to export the image data to tiff in order can be analyzed in Matlab or other software. In this case, we analyze the image of the GIS software. The GIS software allows us to load the other geographic data from online, make a section, and easier to add a feature such as the border of the study area, dam location, georeferenced image from publications. Moreover, the GIS software has a simple mathematical calculator that can be used for image stacking and time series analysis.

Before calculating the time series analysis, we need to do calibration of the input of tiff data (Geo_Disp_LOS_m_filt.tiff). As we know, there is several InSAR image that has noise from the atmospheric signal, which make the undeformed area in the study area as if experiencing deformation but in the same rate (from $0.01 \mathrm{~m}-0.04 \mathrm{~m}$ ) as we can see in the following Fig.3. After checking all data, we pull up or pull down the undeformed reference point to zero levels of deformation.

The next step is time series analysis. The time series analysis itself helps us to track deformations trough time in our study area. Furthermore, we can make a prediction of the mud eruption in our study area based on the exponential of subsidence. The processed atmospheric signal data above is then processed by computing or by applying time-series linear equation $\mathrm{d}=\mathrm{Gm}$.

$d=G m \rightarrow\left[\begin{array}{c}0 \\ \varphi_{1}(P) \\ \varphi_{2}(P)\end{array}\right]=\left[\begin{array}{ccc}1 & 0 & 0 \\ 1 & -1 & 0 \\ 0 & 1 & -1\end{array}\right]\left[\begin{array}{l}\emptyset_{1}(P) \\ \emptyset_{2}(P) \\ \emptyset_{3}(P)\end{array}\right]$

Where $\mathrm{d}$ is data vector of InSAR unwrapped phase data (Geo_Disp_LOS_m_filt), $m$ is the deformation of each SAR image in a particular time $\left(\mathrm{mt}_{0}, \mathrm{mt}_{1}, \mathrm{mt}_{2}, \mathrm{mt}_{3}, \ldots . \mathrm{mt}_{\mathrm{n}}\right)$, and $\mathrm{G}$ is the interferogram baseline network model (in which every subset is connected to). We assumed that $\mathrm{mt}_{0}$ is zero deformation. In this project, we doing time series in thirteen data set with the temporal baseline is 24 days, where we only choose a data set that has a continued timeline (Fig.4). Thus, it will be easier to create time series because we only need to add the InSAR deformation data of $\mathrm{m}\left(\mathrm{t}_{0}\right)+\mathrm{d}\left(\mathrm{t}_{1}\right)$ to get $\mathrm{mt}_{1}$, add $\mathrm{m}\left(\mathrm{t}_{1}\right)+\mathrm{d}\left(\mathrm{t}_{2}\right)$ to get $\mathrm{mt}_{2}$, etc. see the Time series in the (Fig. 4). In this study area, the identified deformation value is negative corresponding to subsidence since the direction azimuth is descending from north to south, and the line of sight (range) is to the east. While calculating the subsidence rate, we just divide the subsidence (in meter) with the period (in day or year) of the two-deformation time or from the slop of the plot between subsidence and time.

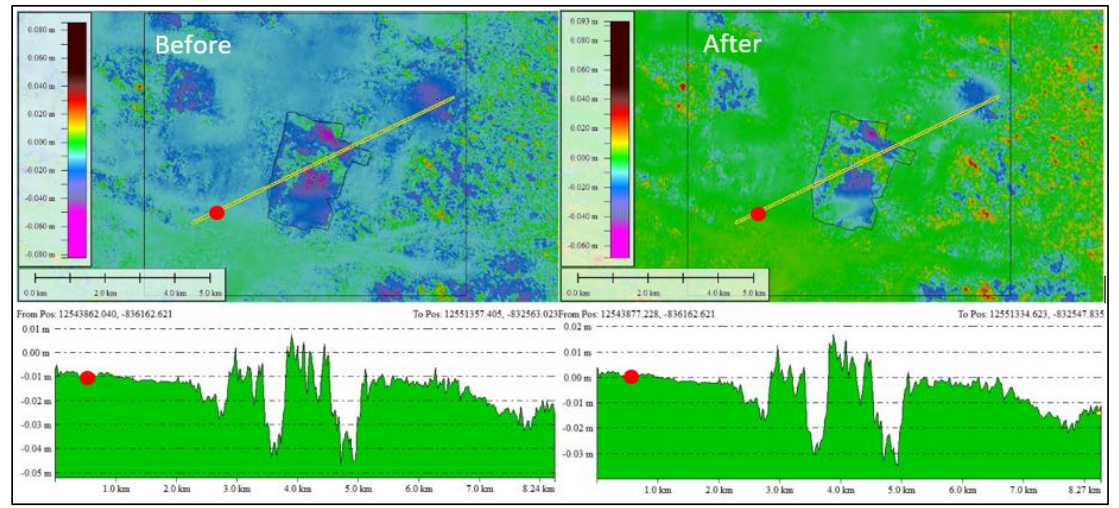

Fig.3. Interferometric SAR image after applying adaptive filter 0.5 (study area in the black box) and Reducing the effect of the atmosphere in Geo_Disp_LOS_m_filt.tiff (red dot is the reference point)

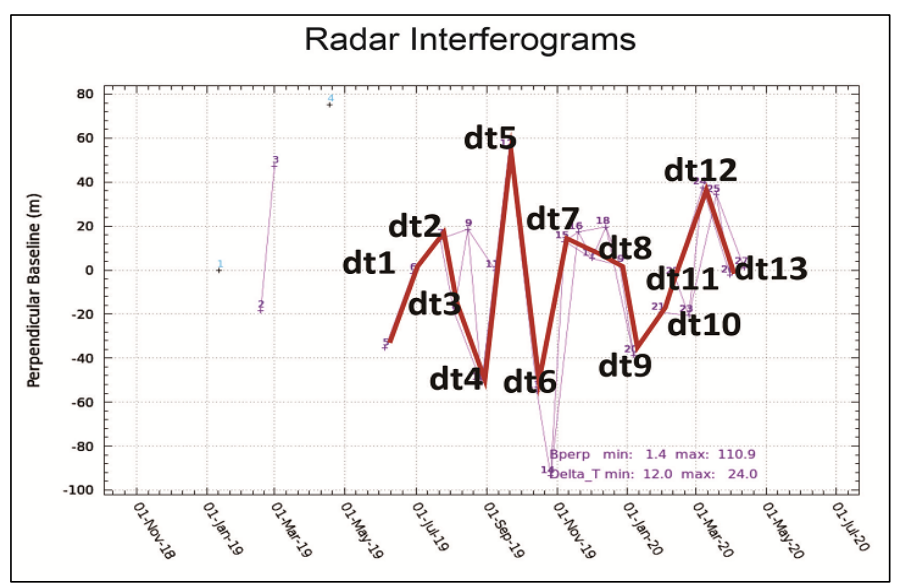

Fig.4. Selected Interferogram

\subsection{Discussion}

As mentioned in the introduction that this area is part of the concession area of one oil company (Lapindo Brantas Ltd). 
Lapindo Brantas has four oil fields in this block area, namely; Tanggulangin, Wunut, Carat, and Watu Dakon oil field. Two of them are located near the LUSI eruption center. They are Tanggulangin in the East of the study area and the Wunut field in the West of the study area (see Fig. 1). Based on the time series InSAR image, we can see several deformations in the area. The deformation in this area corresponds to the LUSI eruption center, and both of the gas field (Fig.5). As we can see the significant deformation is still happening in the Northeast and the West of the levee area until now, where the deformation also happened in the past in the North East levee wall and the west region in the railroad (Istadi et al. 2012). Therefore, the government or operator should pay attention to this area highly deformed area to prevent dam failure.

From the time series map, we choose and plot three points reference in time series graph to know the subsidence rate in those three depocenters. The first point is corresponding to the LUSI, the second point, which is located in the East of the study area is corresponding to the Tanggulangin gas field, and the third point is located in the West of study area corresponding to Wunut gas field (Fig.6). This subsidence rate also becomes necessary in this area because this area is a flat and low elevation area; therefore, a significant subsidence rate within a year can lead to sinking and flooding when entering the rainy season.

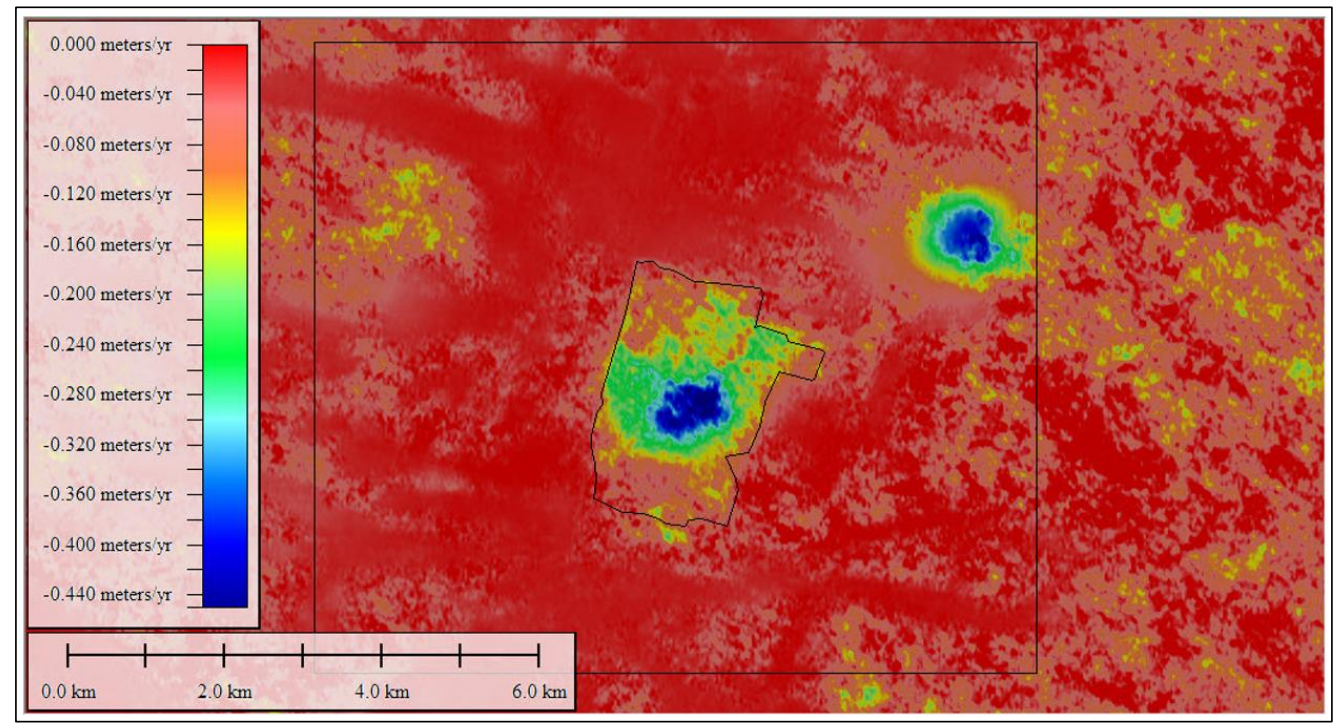

Fig.5. Average subsidence velocity in the study area, in the middle of the study area corresponding to Lusi, in the Northeast area is the Tanggulangin gas field and in the West area is the Wunut gas field.

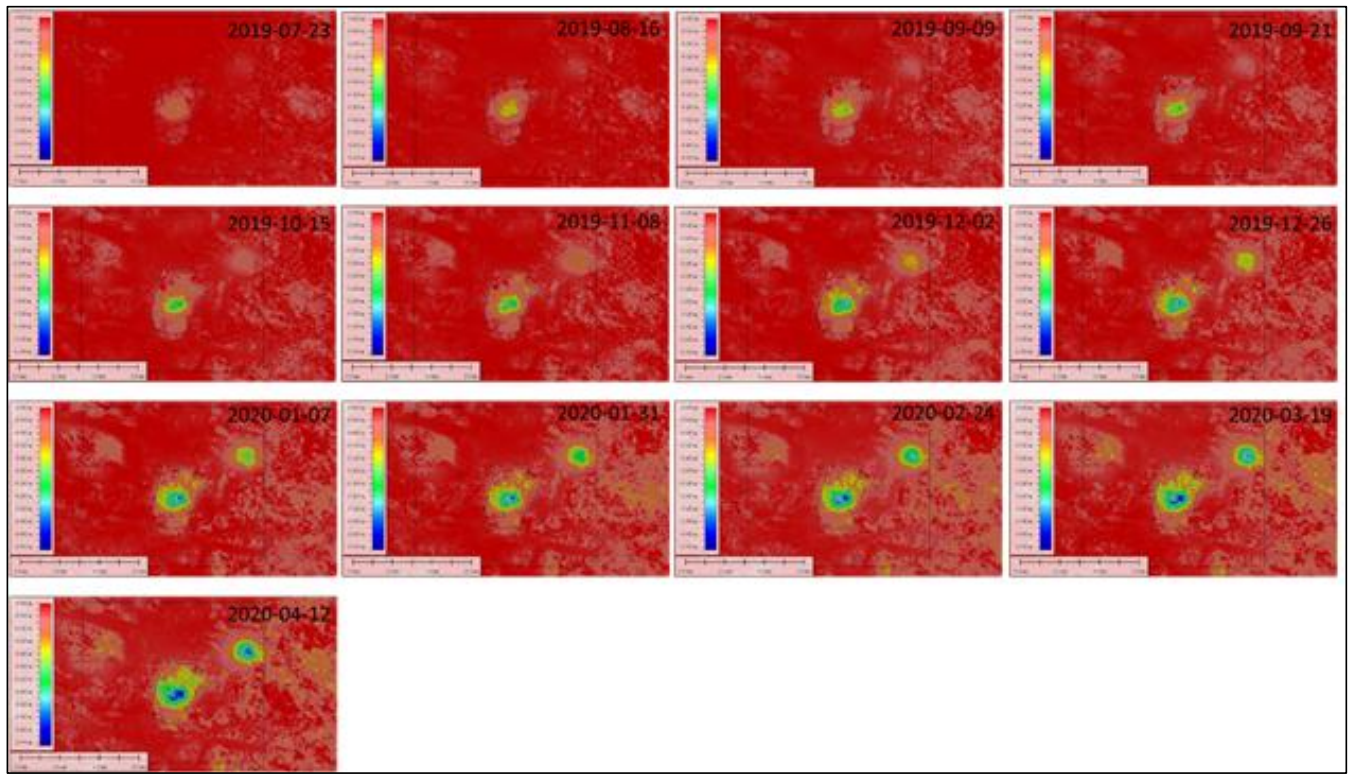

Fig.6. Time series analysis with temporal baseline maximum of 24 days

From the graph, we can see that there is a change in the subsidence rate or displacement velocity of each point (Fig.7). The subsidence rate change in the gas field must be caused by the increase of gas production in the gas field. As reported by the online media, that Lapindo Brantas will increase twice their production by the end of this year. That is mentioned in the news that the production of the gas field in 2018 to 2019 is around 1.1 million $\mathrm{m}^{3}$ gas/day, and they will increase the production twice to 2.2 million $\mathrm{m}^{3}$ gas/day total from two gas fields. This gas production account for the significant subsidence of the Tanggulangin area and the Wunut area from $0.22 \mathrm{~m} / \mathrm{yr}$ to $0.6 \mathrm{~m} / \mathrm{yr}$ and from $0.15 \mathrm{~m} / \mathrm{yr}$ to $0.3 \mathrm{~m} / \mathrm{yr}$, respectively. From the graph, we also can see that the production increase in the Tanggulangin area starts around early October, while in Wunut area begins at the end of December 2019 (Fig. 7). 
Inside the LUSI area, the subsidence rate is decreased nonlinearly through time, which is agree with Davies et al., (2011) flow rate model. Davies et al. (2011) suggest that the flowrate of the LUSI will decrease to less than 100 liters/day in a minimum of 26 days (Fig.8). The other estimation research is by Istadi et al. (2009) predict that the source of mud will be depleted in 23-35 days. However, according to Davies, this analysis is flawed because the eruption will continue after the mud source depleted, and they use a constant eruption rate rather than reducing through time.

Then in this study, we plot the subsidence rate from our research with the initial subsidence rate acquired from Abidin et al. (2008). Abidin analyzes the data taken from a GPS database that has an initial subsidence rate is ranging from 14 meters/year to 6.5 meters/year (exponentially decrease) near the vent center of mud volcano from May 2006 to early 2017 (Figure 8). This research is also supported by Deguchi et al. (2007), which show the same result from InSAR data, where from October to November 2006, the maximum subsidence rate was 12.4 meters/year and from November 2006 to January 2007 was 7.3 meters/year (Fig.8). However there also a publication from Shirzae et al. (2015) suggest that average deformation velocity from InSAR data during early eruption phase (2006$2007)$ is only $80 \mathrm{~cm} /$ year while during while the average deformation velocity in the Lusi and Wunut during 2006 to early 2011 is about $5 \mathrm{~cm} /$ year to $8 \mathrm{~cm} /$ year, respectively. This research from Shirzae et al. (2015) and one of the results from Deguchi et al. (2007) shows meager subsidence rate in the early time of the eruption. This mistake is because they use a longer temporal baseline that will result in the phase unwrapping problem due to a very high deformation rate in a small area.

Finally, from the plot of the subsidence rate in the logarithmic scale from a few works of literature mentioned above, we can predict when is the subsidence rate decrease, which is linear with the volume of mud erupted, or flow rate of eruption is not significant anymore. In this case, we determine the subsidence rate is less than $1 \mathrm{~cm}$ per year is achieved in 2036 or after 30 years since the first eruption day. The result of this project is still linear with the other method of prediction of the longevity of mud eruption.

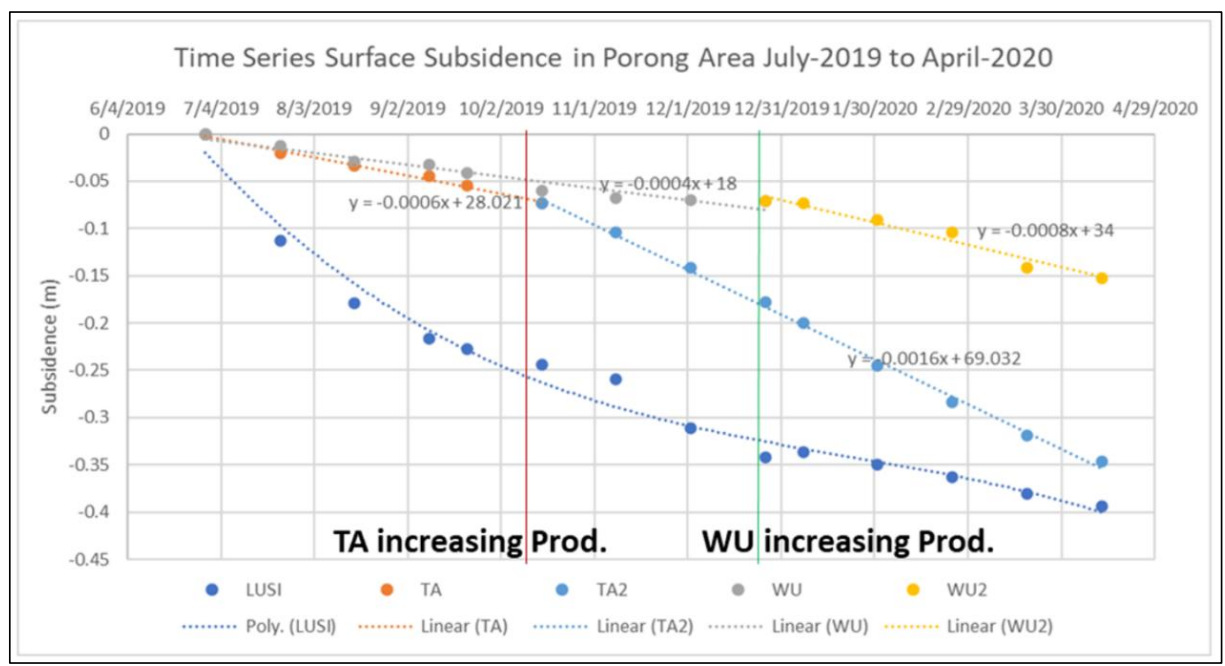

Fig.7. Time series of surface subsidence in three reference point $(\mathrm{TA}=$ Tanggulangin; $\mathrm{WU}=\mathrm{Wunut})$

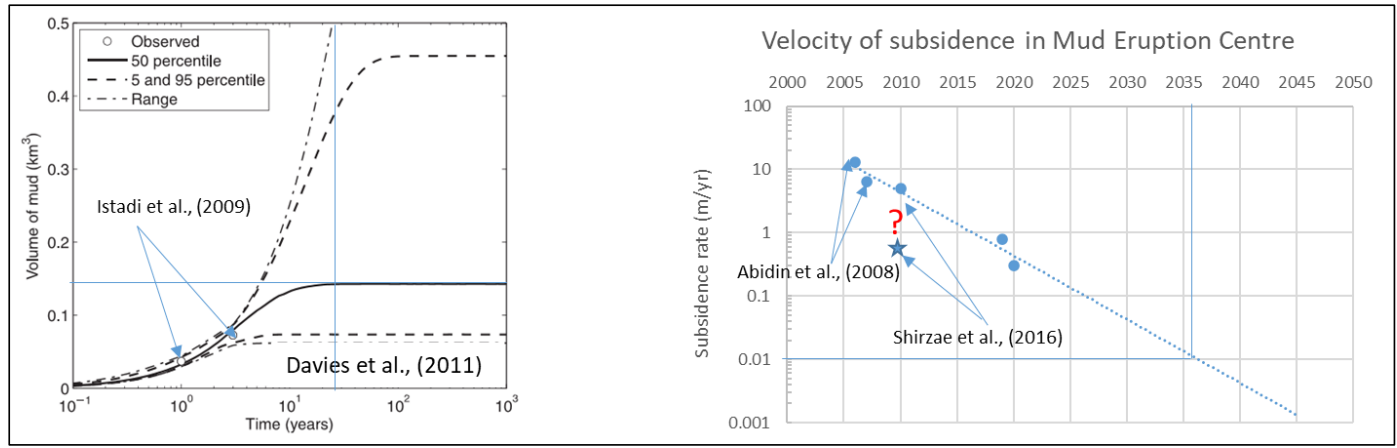

Fig.8. Mud eruption longevity prediction from Davies et al., 2011 (left) and from this research (right)

\section{Conclusion}

In this study, we were successfully processing and applied InSAR to detect and calculate deformation (Time Series) within the study area in Porong, Sidoarjo. During 2019-2020, the subsidence rate in the Porong area due to the mud volcanoes is exponentially decreasing in one year from $0.9 \mathrm{~m} / \mathrm{yr}-0.3 \mathrm{~m} / \mathrm{yr}$. Due to Field production, the Porong area is experiencing more than twice the increase of subsidence rate from $0.22 \mathrm{~m} / \mathrm{yr}$ to 0.6 $\mathrm{m} / \mathrm{yr}$ in the Tanggulangin area and twice subsidence rate in the Wunut area $(0.15 \mathrm{~m} / \mathrm{yr}-0.3 \mathrm{~m} / \mathrm{yr})$. This study and the previous study from Davies et al. (2011) suggest that LUSI will stop to erupt the mud in 2036 (after 30 years) from the subsidence rate and mud discharge rate, respectively.

\section{Acknowledgements}

The research was supported by the ErSE 3900 InSAR Course project. The authors thank the King Abdullah Universityof Science and Technology for facilities support.

\section{References}

Abidin H.Z., Kusuma M.A., Andreas H., Gamal M., and Sumintadireja P., 2008. GPS-Based Monitoring of Surface Displacements in the Mud Volcano Area, Sidoarjo, East Java. Observing our Changing Earth: 
Proceedings of the 2007 IAG General Assembly, Perugia, Italy, July 2 - 13, 2007.

Berardino, P., G. Fornaro, R. Lanari, and E. Sansosti., 2002. “A New Algorithm for SurfaceDeformation Monitoring Based on Small Baseline DifferentialSAR Interferograms." IEEETransactions on Geoscience and Remote Sensing 40 (11): 2375-2383.

Davies., R.J., Mathias S.A., Swarbrick R.E., and Tingay M.J., 2011. Probabilistic longevity estimates for the LUSI mud volcano, East Java. Journal of the Geological Society, London, Vol. 168, 2011, pp. 517-523. doi: 10.1144/0016-76492010-129.

Deguchi, T., Y. Maruyama, and C. Kobayashi., 2007. Monitoring of Deformation Caused by the Development of Oil and Gas Field Using PALSAR and ASTER Data, Powerpoint presentation file, 14 January, ERSDAC (Earth Remote Sensing Data Analysis Center), Japan.

Istadi B.P., Pramono G.H., Sumintadireja P., and Alam S., 2009. Modeling study of growth and potential geohazard for LUSI mud volcano: East Java, Indonesia. Marine and Petroleum Geology 26 (2009) 1724-1739.

Istadi B.P., Wibowo H.T., Sunardi E., Hadi S., and Sawolo N., 2012. Mud Volcano and Its Evolution. Earth Science book chapter, Intech Open, DOI:10.5772/24944

Just, D., and R. Bamler. 1994. "Phase Statistics of Interferograms with Applications to SyntheticAperture Radar." Applied Optics 33 (20): 4361-4368.

Sawolo N., Sutriono E., Istadi B.P., Darmoyo A.B., 2010. Was LUSI caused by drilling? - Authors reply to discussion. Marine and Petroleum Geology 27 (2010), 1658-1575.

Schiller, D.M., Seubert, B.W., Musliki, S., Abdullah, M., 1994. The reservoirpotential of globigerinid sands in Indonesia. In: Proceedings of the $23^{\text {rd Annual }}$ Convention, Proceedings of the Indonesian Petroleum Association, vol. 1, p. $189 \mathrm{ff}$.

Schmidt, D. A., and R. Burgmann. 2003. "Time-Dependent Land Uplift and Subsidence in theSanta Clara Valley, California, from a Large Interferometric Synthetic Aperture Radar Data Set."Journal of Geophysical Research 108 (B9): 2416-2428.

Shirzae M., Rudolph M.L., and Manga M., 2015. Deep and shallow sources for the Lusi mud eruption revealed by surface deformation. Geophys. Res. Lett., 42, 5274 5281, doi:10.1002/2015GL064576.

Willumsen, P. and Schiller, D.M., 1994. High quality volcaniclastic sandstone reservoirsin East Java, Indonesia. In: 23rd Annual Convention, vol. I. IPA, pp. $101-111$

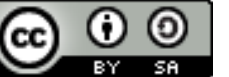

(C) 2020 Journal of Geoscience, Engineering, Environment and Technology. All rights reserved. This is an open access article distributed under the terms of the CC BY-SA License (http://creativecommons.org/licenses/by-sa/4.0/). 